Norbert Gorny $\cdot$ Bernhard Schink

\title{
Complete anaerobic oxidation of hydroquinone by Desulfococcus sp. strain Hy5: indications of hydroquinone carboxylation to gentisate
}

\author{
Received: 22 December 1993 / Revised received: 24 February 1994 / Accepted: 18 March 1994
}

\begin{abstract}
The sulfate-reducing strain Hy5 was able to grow with hydroquinone as sole source of carbon and energy. In experiments with dense cell suspensions, several indications were found that gentisate was the first intermediate in anaerobic degradation of hydroquinone: (1) degradation of hydroquinone was accelerated by addition of bicarbonate; (2) cell suspensions grown with hydroquinone oxidized gentisate at a rate similar to that of suspensions grown with gentisate, whereas the latter were not able to degrade hydroquinone in the presence of chloramphenicol; (3) in SDS-PAGE analysis of cell-free extracts of strain Hy5, two additional protein bands were found after growth with hydroquinone that were not detected in cells grown with gentisate, probably representing a hydroquinone carboxylating enzyme. A corresponding enzyme activity could not be detected. In cell-free extracts of hydroquinone-grown strain $\mathrm{Hy} 5$, the specific acyl-CoA ligase activity with gentisate as substrate was detected at $70 \mathrm{nmol} \times \mathrm{mg}^{-1} \times \mathrm{min}^{-1}$. Gentisyl-CoA was enzymatically reduced to several unidentified nonaromatic products in the presence of dithionite-reduced methyl viologen.
\end{abstract}

Key words Anaerobic degradation - Aromatic compounds $\cdot$ Carboxylation $\cdot$ Sulfate-reducing bacteria

\section{Introduction}

The abundance of each of the three dihydroxybenzenes catechol, resorcinol, and hydroquinone in nature differs considerably. While catechol and resorcinol are rarely found in the secondary metabolism of higher plants (Pridham 1965), hydroquinone is very common and widely

N. Gorny · B. Schink (区)

Fakultät für Biologie, Universität Konstanz, Postfach 5560, D-78434 Konstanz, Germany, Tel. +49-7531-882140;

Fax +49-7531-882966; E-mail bischink @nyx. uni-konstanz.de distributed, e.g., in plants of the families Ericaceae and Rosaceae (Conn 1964).

Anaerobic degradation of dihydroxybenzenes has been reported for more than 20 years (Healy and Young 1979), but until now a degradation pathway could be proposed only for resorcinol, which is easily oxidized by fermenting, sulfate-reducing, or nitrate-reducing bacteria (Schnell et al. 1989; Kluge et al. 1990; Gorny et al. 1992). Anaerobic degradation of catechol is found predominantly among sulfate-reducing bacteria of the genera Desulfobacterium and Desulfotomaculum (Schnell et al. 1989; Kuever et al. 1993), but fermentative degradation in undefined cultures has also been described (Szewzyk et al. 1985).

Anerobic degradation of hydroquinone is known to occur in two isolates, the fermenting strain HQGö1 (Szewzyk and Schink 1989) and the sulfate-reducing strain Hy5 (Schnell et al. 1989). It was supposed in an earlier investigation that phenol might be the first intermediate in anaerobic hydroquinone breakdown (Szewzyk et al. 1985), but recently we demonstrated that with the fermenting strain HQGö1, carboxylation to gentisate and further reductive dehydroxylation were the key reactions (Gorny and Schink 1994).

The work described in this paper was undertaken to determine whether Desulfococcus Hy5 uses analogous reactions for anaerobic degradation of hydroquinone, or whether sulfate-reducing bacteria use a different degradation pathway.

\section{Materials and methods}

Media and growth conditions

The mineral medium used for cultivation was the same as described for isolation of strain Hy5 (Schnell et al. 1989). Strain Hy5 was grown in 1.21 infusion bottles sealed with rubber septa under a $\mathrm{N}_{2} / \mathrm{CO}_{2}(90: 10)$ atmosphere with $2 \mathrm{mM}$ hydroquinone or gentisate and $20 \mathrm{mM} \mathrm{Na} \mathrm{SO}_{4}$ in the dark at $28^{\circ} \mathrm{C}$. Growth was recorded by measuring the optical density at $578 \mathrm{~nm}\left(\mathrm{OD}_{578}\right)$. 
Experiments with dense cell suspensions

Cells were harvested in the late exponential phase of growth $\left(\mathrm{OD}_{578}=0.3-0.4\right)$ in an anoxic chamber (Coy, Ann Arbor, Mich. USA) under $\mathrm{N}_{2} / \mathrm{H}_{2}(95: 5)$. Cell pellets were obtained by centrifugation in gas-tight bottles at $9000 \times \mathrm{g}$ for $30 \mathrm{~min}$ at $4^{\circ} \mathrm{C}$ and washed once with $50 \mathrm{mM}$ potassium phosphate buffer ( $\mathrm{pH} 7.0)$ supplemented with $2 \mathrm{~m} M$ dithioerythritol, $5 \mathrm{mM} \mathrm{MgCl}$ and 20 $\mathrm{mM} \mathrm{Na} \mathrm{SO}_{4}$. After another centrifugation step, cell density was adjusted to $\mathrm{OD}_{578}=10$. Experiments were performed in $5 \mathrm{ml} \mathrm{Hun-}$ gate tubes under $\mathrm{N}_{2}$ or $\mathrm{N}_{2} / \mathrm{CO}_{2}(90: 10)$. Samples for chemical analyses were taken with gas-tight syringes and diluted with $0.1 \mathrm{M}$ $\mathrm{H}_{3} \mathrm{PO}_{4}$.

Preparation of cell extracts and enzyme assays

Cell-free extracts were prepared anoxically by French pressure cell treatment $(138 \mathrm{MPa})$ of freshly harvested cells or frozen cells stored in liquid nitrogen. Cell debris was removed by centrifugation at $15000 \times g$ for $30 \mathrm{~min}$ at $4^{\circ} \mathrm{C}$.

Enzymes were assayed at $25^{\circ} \mathrm{C}$ either by discontinuous HPLC or in continuous photometric assays. The head spaces of test vessels were evacuated and gassed with nitrogen after sealing with gas-tight rubber septa.

Aryl carboxyl-CoA synthetase (acyl-CoA synthetase), carboxylation of hydroquinone, reduction of gentisyl-CoA, glutaryl-CoA dehydrogenase (EC 1.3.99.7) and glutaconyl-CoA decarboxylase (EC 4.1.1.70) were tested as described recently (Gorny and Schink 1994).

Carbon monoxide dehydrogenase (EC 1.2.99.2) was assayed by recording benzyl viologen reduction at $578 \mathrm{~nm}$ upon addition of carbon monoxide (Diekert and Thauer 1978).

Crotonase (EC 4.2.1.17), 3-hydroxybutyryl-CoA dehydrogenase (EC 1.1.1.157), and $\beta$-ketothiolase were measured by standard methods (Bergmeyer 1983).

\section{SDS-Polyacrylamide gel electrophoresis (SDS-PAGE)}

Samples and gels were prepared according to standard methods (Garfin 1990). SDS-PAGE was performed according to Laemmli (1970) on $4 \%(\mathrm{w} / \mathrm{w})$ stacking and $10 \%(\mathrm{w} / \mathrm{w})$ resolving gels. Proteins were stained with Coomassie Brilliant Blue R-250.

\section{Analytical methods}

Aromatic compounds and CoA-esters were analyzed by HPLC (Brune and Schink 1990). Peak areas were quantified by comparison with internal and external standards. Aromatic CoAesters were identified by comparison of their retention times and UV spectra with those of chemically synthesized reference compounds.

Sulfide was determined as described by Cline (1969). Protein was quantified as described by Bradford (1976), with bovine serum albumin as a standard.

\section{Chemicals}

Gentisyl-CoA was prepared enzymatically as described recently (Gorny and Schink 1994). 2-Hydroxybenzoyl-CoA and 3-hydroxybenzoyl-CoA were synthesized according to Merkel et al. (1989).

Marker proteins were obtained from Pharmacia (Freiburg, Germany). All other chemicals were obtained from Boehringer (Mannheim, Germany), Fluka (Neu-Ulm, Germany), Merck (Darmstadt, Germany), Serva (Heidelberg, Germany), and Sigma (Deisenhofen, Germany).

\section{Results}

Growth experiments and stoichiometry of hydroquinone and gentisate degradation

Hydroquinone and gentisate were oxidized completely to $\mathrm{CO}_{2}$, while sulfate was reduced to sulfide in nearly stoichiometric amounts according to the following equations:

$$
\begin{aligned}
4 \mathrm{C}_{6} \mathrm{H}_{4}(\mathrm{OH})_{2} & +13 \mathrm{SO}_{4}{ }^{2-}+13 \mathrm{H}^{+} \rightarrow 24 \mathrm{CO}_{2} \\
& +13 \mathrm{HS}^{-}+12 \mathrm{H}_{2} \mathrm{O} \\
4 \mathrm{C}_{6} \mathrm{H}_{3}(\mathrm{OH})_{2} \mathrm{COO}^{-} & +13 \mathrm{SO}_{4}{ }^{2-}+17 \mathrm{H}^{+} \rightarrow 28 \mathrm{CO}_{2} \\
& +13 \mathrm{HS}^{-}+12 \mathrm{H}_{2} \mathrm{O}
\end{aligned}
$$

With gentisate as electron and carbon source, the doubling time $\left(t_{\mathrm{d}}\right)$ was about $44 \mathrm{~h}$. In contrast, strain Hy5 grew only half as fast with hydroquinone $\left(t_{\mathrm{d}}=96-99 \mathrm{~h}\right)$. Molar growth yields with these aromatic substrates were very different. Cultures grown with gentisate produced more than $40 \%$ more cell material than those grown with hydroquinone. The growth and degradation stoichiometries are summarized in Table 1.

\section{Degradation of alternative substrates \\ by dense cell suspensions of strain Hy 5}

Hydroquinone, gentisate, and benzoate were degraded by hydroquinone-grown cell suspensions of strain Hy5 in the presence of $20 \mathrm{mM}$ sodium sulfate, even if chlorampheni-

Table 1 Stoichiometry of hydroquinone and gentisate oxidation by strain $\mathrm{Hy} 5$

\begin{tabular}{lllll}
\hline Substrate & $\begin{array}{l}\text { Substrate } \\
\text { added } \\
\text { [mmol] }\end{array}$ & $\begin{array}{l}\text { Sulfide } \\
\text { produced } \\
{[\text { mmol] }}\end{array}$ & $\begin{array}{l}\text { Cell dry } \\
\text { mass } \\
\text { formed } \\
{[\mathrm{mg}]}\end{array}$ & $\begin{array}{l}\text { Electron } \\
\text { recovery } \\
{[\%]}\end{array}$ \\
\hline $\begin{array}{l}\text { Hydroquinone } \\
\text { Gentisate }\end{array}$ & 2.0 & 5.5 & 45.6 & 98 \\
\hline
\end{tabular}

a The amount of cell mass formed was calculated from optical density measurements via an eperimentally determined conversion factor $\left(\mathrm{OD}_{578}=1.0 \cong 177 \mathrm{mg}\right.$ cell mass $\left.\mathrm{ml}^{-1}\right)$

b The amount of substrate assimilated was calculated using the following equations:

$17 \mathrm{C}_{6} \mathrm{H}_{4}(\mathrm{OH})_{2}+2 \mathrm{CO}_{2} \rightarrow 26\left\langle\mathrm{C}_{4} \mathrm{H}_{7} \mathrm{O}_{3}\right\rangle$

$17 \mathrm{C}_{6} \mathrm{H}_{3}(\mathrm{OH})_{2} \mathrm{COOH}+40 \mathrm{H}_{2} \mathrm{O} \rightarrow 26\left\langle\mathrm{C}_{4} \mathrm{H}_{7} \mathrm{O}_{3}\right\rangle+15 \mathrm{CO}_{2}$

Table 2 Degradation of aromatic compounds by dense cell suspensions of strain Hy5 $\left(\mathrm{OD}_{578}=15\right)$ in the presence of chloramphenicol $\left(30 \mu \mathrm{g} \mathrm{ml}^{-1}\right)$

\begin{tabular}{lll}
\hline & \multicolumn{2}{l}{ Growth substrate } \\
\cline { 2 - 3 } & $\begin{array}{l}\text { Hydroquinone } \\
{\left[\mathrm{nmol} \cdot \mathrm{min}^{-1}\right.} \\
\left.(\mathrm{mg} \text { protein })^{-1}\right]\end{array}$ & $\begin{array}{l}\text { Gentisate } \\
{\left[\mathrm{nmol} \cdot \mathrm{min}^{-1}\right.} \\
\left.(\mathrm{mg} \text { protein })^{-1}\right]\end{array}$ \\
\hline Hydroquinone & 3.2 & $<0.1$ \\
Gentisate & 3.3 & 4.7 \\
Benzoate & 4.4 & 5.0 \\
\hline
\end{tabular}


col was added to the assay mixtures (Table 2). In contrast to suspensions pre-grown with hydroquinone, no decrease in the hydroquinone concentration was measured in assays with suspensions of gentisate-grown cells. Similar rates of degradation of gentisate and benzoate were detected with both suspensions. None of the suspensions showed phenol, 2-hydroxybenzoate, or 3-hydroxybenzoate degrading activity.

The rate of hydroquinone degradation depended on the presence of bicarbonate. With $50 \mathrm{~m} M$ sodium bicarbonate, hydroquinone was oxidized at a rate of $2.8 \mathrm{nmol} \times$ $\min ^{-1} \times(\operatorname{mg} \text { protein })^{-1}$, whereas without bicarbonate slow degradation $\left[0.4 \mathrm{nmol} \times \mathrm{min}^{-1} \times(\mathrm{mg} \text { protein })^{-1}\right]$ could be detected only after $2 \mathrm{~h}$ of incubation. No influence of bicarbonate on the degradation rate was observed when gentisate was used as substrate; the aromatic substrate was degraded at a rate of $3.1 \mathrm{nmol} \times \mathrm{min}^{-1} \times(\mathrm{mg}$ protein $)^{-1}$, both in the presence and absence of bicarbonate.

Reduction and carboxylation of hydroquinone in cell-free extracts

Reduction of hydroquinone in cell-free extracts was assayed in a discontinuous anoxic test. Upon addition of Ti(III) citrate, dithionite-reduced methyl or benzyl viologen, NAD $(\mathrm{P}) \mathrm{H}$, or formate $(0.5-2.5 \mathrm{~m} M$ each), no decrease in hydroquinone concentration was detected. Formation of phenol was also not observed.

In discontinuous assays with cell-free extracts of hydroquinone-grown cells of strain Hy5, a carboxylating activity forming gentisate from hydroquinone and $\mathrm{CO}_{2}$ could not be measured. Even in the presence of bicarbonate at high concentrations $(0.5 \mathrm{M})$, ATP $(1-5 \mathrm{mM}), \mathrm{MnCl}_{2}$ $(0.1-0.3 \mathrm{~m} M)$ or cofactors such as biotin, thiamine pyrophosphate, or pyridoxal phosphate $(0.1 \mu \mathrm{M}$ each), gentisate was not detected by HPLC analysis. In addition, isotope exchange experiments were performed; no measurable exchange between the carboxyl function of gentisate and ${ }^{14} \mathrm{C}$-carbonate was catalyzed by cell-free extracts of hydroquinone-grown cells.

\section{SDS-PAGE of cell-free extracts}

Cell-free extracts of strain Hy5 were analyzed by SDSPAGE with respect to differences in protein patterns. In extracts of hydroquinone-grown cells, two additional protein bands were detected that did not occur in extracts of cells grown with gentisate. A weak band was found at 80 $\mathrm{kDa}$ and a stronger one at $41 \mathrm{kDa}$ (Fig. 1).

Enzyme activities in cell-free extracts of strain $\mathrm{Hy} 5$

An aryl carboxyl-CoA synthetase activity in cell-free extracts of strain Hy 5 formed the corresponding CoA-esters of gentisate and salicylate in an ATP-and $\mathrm{Mg}^{2+}$-dependent reaction. The specific activity with gentisate was 56-71
Fig. 1 SDS-PAGE of cell-free extracts of strain Hy5. (1) Marker proteins: $94,67,43$, 30 , and $20.1 \mathrm{kDa}(2)$ cells grown with gentisate (3) cells grown with hydroquinone. Arrows Additional protein bands detected in cell-free extracts of hydroquinone-grown cells

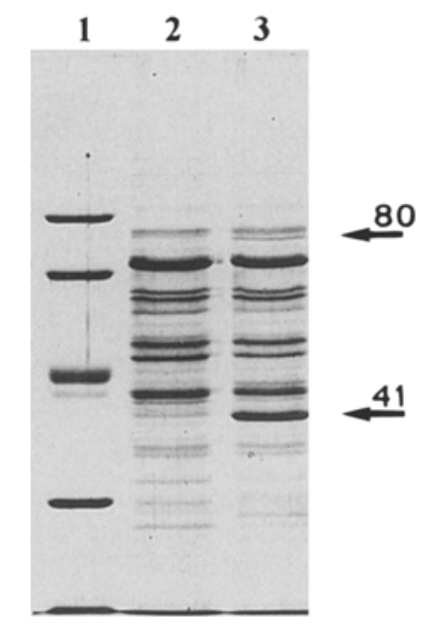

Table 3 Enzyme activities in cell-free extracts of strain Hy5 grown with hydroquinone

\begin{tabular}{ll}
\hline Enzyme & $\begin{array}{l}\text { Specific activity } \\
{\left[\mathrm{nmol} \cdot \mathrm{min}^{-1}\right.}\end{array}$ \\
& $\left.(\mathrm{mg} \text { protein })^{-1}\right]$ \\
\hline Aryl carboxyl-CoA synthetase & $56-71^{\mathrm{a}}$ \\
& $45-51^{\mathrm{b}}$ \\
Glutaryl-CoA dehydrogenase & $45-55$ \\
Glutaconyl-CoA decarboxylase & $27-31$ \\
Crotonase & $8390-8800$ \\
3-Hydroxybutyryl-CoA dehydrogenase & $193-203$ \\
CO dehydrogenase & $4460-4890$ \\
\hline
\end{tabular}

a With gentisate as substrate

b With salicylate as substrate

c With benzyl viologen as electron acceptor

nmol $\times \min ^{-1} \times(\text { mg protein })^{-1}$. The activity with salicylate was in the same order of magnitude, while other tested benzoic acid derivatives were not activated (Table 3).

In several assays the reduction of enzymatically synthesized gentisyl-CoA by cell-free extracts of strain Hy 5 was tested. Gentisyl-CoA disappeared in the test system at a specific rate of $11 \mathrm{nmol} \times \mathrm{min}^{-1} \times(\mathrm{mg} \text { protein })^{-1}$ if dithionite-reduced methyl viologen was added as electron donor, but a defined reduction product could not be detected. In contrast, four different peaks were found in HPLC analysis; all had a high absorption maximum at $260 \mathrm{~nm}$. Using an HPLC method with a linear methanol gradient from 10\%-70\% methanol within 6 min starting 1 min after injection, product peaks were detected in a range from 6.2-6.8 min. Neither 2- or 3-hydroxybenzoyl$\mathrm{CoA}$, benzoyl-CoA, nor pimelyl-CoA was found to coelute with these compounds. With alternative electron donors such as Ti(III) citrate, $\mathrm{NAD}(\mathrm{P}) \mathrm{H}$, or formate, gentisyl-CoA reduction could not be detected.

Enzyme activities necessary for anaerobic breakdown of benzoate to acetyl-CoA and for complete oxidation via the carbon monoxide pathway were present in cell-free extracts of hydroquinone-grown cells of strain Hy5 (Table 3). 


\section{Discussion}

Hydroquinone and gentisate were oxidized completely via the carbon monoxide-dehydrogenase pathway by the marine Desulfococcus strain Hy5. Therefore, identical amounts of electrons were obtained for sulfate reduction from both substrates [Eqs. (1) and (2)] and consequently, similar growth yields would be expected. However, data obtained from growth experiments showed that $40 \%$ more dry matter was produced from gentisate. This difference could be based on several reasons:

(1) The doubling time with hydroquinone is twice as long as with gentisate. Therefore, more energy is used up in maintenance metabolism (Pirt 1965)

(2) Hydroquinone is the more hydrophobic compound and will interact more intensely with the cell membrane, causing destabilization (Conn 1964).

(3) One step in hydroquinone degradation that does not occur in the gentisate pathway consumes a large part of the energy budget of the bacteria. This could be the carboxylation reaction forming gentisate from hydroquinone. Indeed, we found indications in favor of this hypothesis.

Hydroquinone oxidation by strain Hy5 was significantly accelerated by addition of bicarbonate; this was not true for gentisate degradation. In hydroquinone-grown cells, all enzymes necessary for gentisate degradation were induced. These observations could be linked by the assumption that the first step in anaerobic hydroquinone degradation is an endergonic carboxylation. Similar results were obtained with the fermenting bacterium HQGö1 (Gorny and Schink 1994). Also with this strain, a higher $Y_{s}$ value was measured with gentisate than with hydroquinone (Szewzyk and Schink 1989).

The induction of degradation capacities is also reflected by the protein patterns of cell-free extracts. In SDS-PAGE analysis, two additional protein bands were detected in extracts from hydroquinone-grown cells that were not found after growth with gentisate. The stronger band at $41 \mathrm{kDa}$ or both additional bands formed might represent a hydroquinone carboxylating enzyme necessary only for hydroquinone degradation and not for gentisate degradation.

No hydroquinone-carboxylating activity could be detected in experiments with cell-free extracts. Neither formation of gentisate from hydroquinone and $\mathrm{CO}_{2}$ nor an isotope exchange between the carboxyl group of gentisate and ${ }^{14} \mathrm{CO}_{2}$ was measured. Such difficulties in measurements of carboxylating enzyme activities are known from studies of anaerobic degradation of phenol (Lack et al. 1991), aniline (Schnell and Schink 1991), o-cresol (Rudolphi et al. 1991), or acetone (Platen and Schink 1991). Indications of a carboxylase have been obtained so far only by indirect assays, e.g., isotope exchange experiments (Tschech and Fuchs 1989). In our investigations with the hydroquinone fermenting strain HQGö1, $\mathrm{CO}_{2}$ fixation was measurable only as formation of the carboxylated end product benzoate (Gorny and Schink 1994). Carboxylation of phenylphosphate was demon- strated in vitro in cell-free extracts of phenol-degrading nitrate-reducing bacteria (Lack and Fuchs 1994).

The further degradation of gentisate was started by conversion to the corresponding CoA-ester through an acyl-CoA ligase activity in cell-free extracts, a common strategy in anaerobic breakdown of many benzoic acid derivatives (Schink et al. 1992). Thereupon gentisyl-CoA was reduced by cell-free extracts to more than one product with absorption at $260 \mathrm{~nm}$, indicating that they were esterified with coenzyme A. Since peaks could not be separated any further, only on-line scans during HPLC measurements were obtained. Nevertheless, retention times differed from those of 2-hydroxy- or 3-hydroxybenzoylCoA, benzoyl-CoA, and pimelyl-CoA.

Reduction of gentisyl-CoA by the fermenting strain HQGö1 is catalyzed by a dehydroxylating reductase forming benzoyl-CoA (Gorny and Schink 1994). A different mechanism of gentisyl-CoA reduction appears to be present in Desulfococcus sp. strain Hy $5^{1}$, probably without forming benzoyl-CoA as an intermediate through reductive elimination of the hydroxyl groups.

Acknowledgement This work was supported by the Deutsche Forschungsgemeinschaft through Schwerpunktprogramm 'Neuartige Reaktionen und Katalysemechanismen bei anaeroben Mikroorganismen'.

\section{References}

Bergmeyer HU (ed) (1983) Methods of enzymatic analysis, vols 2-3. VCH, Weinheim

Bradford MM (1976) A rapid and sensitive method for the quantitation of protein using the principle of protein-dye binding. Anal Biochem $72: 248-254$

Brune A, Schink B (1990) Pyrogallol-to-phloroglucinol conversion and other hydroxyl-transfer reactions catalyzed by cell extracts of Pelobacter acidigallici. I Bacteriol 172:1070-1076

Cline JD (1969) Spectrophotometric determination of hydrogen sulfide in natural waters. Limnol Oceanogr 14:454-458

Conn EE (1964) Enzymology of phenolic biosynthesis. In: Harborne JB (ed) Biochemistry of phenolic compounds. Academic Press, New York London, pp 399-436

Diekert G, Thauer RK (1978) Carbon monoxide oxidation by Clostridium thermoaceticum and Clostridium formicoaceticum. J Bacteriol 136:597-606

Garfin DE (1990) One-dimensional gel electrophoresis. In: Deutscher MP (ed) Methods in enzymology, vol 182. Academic Press, San Diego, pp 425-441

Gorny N, Schink B (1994) Hydroquinone degradation via reductive dehydroxylation of gentisyl-CoA by a strictly anaerobic fermenting bacterium. Arch Microbiol 161:25-32

Gorny N, Wahl G, Brune A, Schink B (1992) A strictly anaerobic nitrate-reducing bacterium growing with resorcinol and other aromatic compounds. Arch Microbiol 158:48-53

Healy IB Ir, Young LY (1979) Anaerobic degradation of eleven aromatic compounds to methane. Eppl Environ Microbiol 38: 84-89

Kluge C, Tschech A, Fuchs G (1990) Anaerobic metabolism of resorcyclic acids ( $m$-dihydroxybenzoic acids) and resorcinol (1,3-benzene-diol) in a fermenting and in a denitrifying bacterium. Arch Microbiol 155:68-74

1 Strain Hy 5 was deposited with the Deutsche Sammlung von Mikroorganismen (DSM), Braunschweig, Germany under no. DSM 8541 
Kuever J, Kulmer J, Jansen S, Fischer U, Blotevogel K-H (1993) Isolation and characterization of a new spore-forming sulfatereducing bacterium growing by complete oxidation of catechol. Arch Microbiol 159:282-288

Lack A, Fuchs G (1994) Evidence that phenol phosphorylation to phenylphosphate is the first step in anaerobic metabolism in a denitrifying Pseudomonas sp. Arch Microbiol 161:132-139

Lack A, Tommasi I, Aresta M, Fuchs G (1991) Catalytic properties of phenol carboxylase. In vitro study of $\mathrm{CO}_{2}: 4$-hydroxybenzoate isotope exchange reaction. Eur J Biochem 197:473479

Laemmil UK (1970) Cleavage of structural proteins during the assembly of the head of bacteriophage T4. Nature 227:680-685

Merkel SM, Eberhard AE, Gibson J, Harwood CS (1989) Involvement of coenzyme A thioesters in anaerobic metabolism of 4hydroxybenzoate by Rhodopseudomonas palustris. J Bacteriol $171: 1-7$

Pirt SJ (1965) The maintenance energy of bacteria in growing cultures. Proc R Soc Lond [Biol] 163:224-289

Platen H, Schink B (1991) Enzymes involved in anaerobic degradation of acetone by a denitrifying bacterium. Biodegradation 1 : 243-251

Pridham JB (1965) Low molecular weight phenols in higher plants. Ann Rev Plant Physiol 16:13-36
Rudolphi A, Tschech A, Fuchs G (1991) Anaerobic degradation of cresols by denitrifying bacteria. Arch Microbiol 155:238-248

Schink B, Brune A, Schnell S (1992) Anaerobic degradation of aromatic compounds. In: Winkelmann $\mathrm{G}$ (ed) Microbial degradation of natural products. VCH, Weinheim, pp 219-242

Schnell S, Schink B (1991) Anaerobic aniline degradation via reductive deamination of 4-aminobenzoyl-CoA in Desulfobacterium anilini. Arch Microbiol 158:511-516

Schnell S, Bak F, Pfennig N (1989) Anaerobic degradation of aniline and dihydroxybenzenes by newly isolated sulfate-reducing bacteria and description of Desulfobacterium anilini. Arch Microbiol $152: 556-563$

Szewzyk U, Schink B (1989) Degradation of hydroquinone, gentisate and benzoate by a fermenting bacterium in pure and defined mixed culture. Arch Microbiol 151:541-545

Szewzyk U, Szewzyk R, Schink B (1985) Methanogenic degradation of hydroquinone and catechol via reductive dehydroxylation to phenol. FEMS Microbiol Ecol 31:79-87

Tschech A, Fuchs G (1989) Anaerobic degradation of phenol via carboxylation to 4-hydroxybenzoate: in vitro study of isotope exchange between ${ }^{14} \mathrm{CO}_{2}$ and 4-hydroxybenzoate. Arch Microbiol 152:594-599 